\title{
Influence of Household Head's Occupational Status on Children's School Attendance in The Democratic Republic of Congo
}

\author{
Bernard Yungu Loleka \\ Kobe University \\ Graduate School of International Cooperation Studies \\ Department of Regional Cooperation Policy Studies \\ 2-1 Rokkodai-cho, Nada-ku, Kobe 657-8501, Japan
}

\begin{abstract}
Parents are primarily responsible for raising children in every society, and because of this, the nuclear family is recognized as an important agent of socialization. If parents can efficiently and joyfully apply all the resources and skills, they possess in order to bring up their children their success rate is dramatically improved. One of the most significant resources in the hands of the parents is occupation. With regards to this, the influence of parental occupation on their children's education continues to attract the attention of many researchers. Using 1-2-3 survey data on employment, this study empirically investigated the particular ways in which parental occupation exerts its effects on primary and secondary school-age children in DRC. Our analysis shows that parental occupation does matter in the DRC, but is expressed through the effect of family origin of household heads.
\end{abstract}

Keywords: Occupational Status; Intergenerational Social Mobility; Children's schooling; The Democratic Republic of Congo

\section{Introduction}

The nuclear family is recognized as an important agent of socialization because from the beginning parents are the primary persons involved in raising children in every society (Usaini \& Abubakar, 2015). This is more specifically achieved if parents can efficiently and joyfully apply both the resources and skills they possess for bringing up their children. One of the most significant resources in the hands of the parents is their occupation. Research confirms what many people intuitively understand, that children of parents with low skilled jobs, especially if these are of a routine domestic or manual nature, are less likely to succeed than children of parents with salaries from big firms (Mayer, 2002). With regards to this, the influence of parental occupation on a child's education continues to attract the attention of many researchers (Ali Shah \& Anwar, 2014; Usaini \& Abubakar, 2015).

In their study on the impact of parent's occupation and family income on children's performance in Southern Punjab, in Pakistan, Ali Shah \& Anwar found that parent's occupation has a significant impact on a child's school performance (Ali Shah \& Anwar, 2014). They argued that parents play an important role in a child's development and therefore parents with good economic status provide better facilities for their children, resulting in better performance. In contrast (Francavilla et al., 2013), in a study on mothers' occupation and their children's schooling in India, found that the correlation between mothers' occupation and their child's schooling was negative. The most compelling evidence of their study implies that women in poorer households are more likely to work, but given the negative correlation, their additional income does not seem sufficient to enable better school attendance.

Measures of family environment, such as parental occupational status, have been shown to be related to a child's ability and educational attainment, however the mechanism by which this parental attribute alters the social trajectory of children has not always been clearly specified (Leibowitz, 1977). One hypothesis is that family-background variables are related to the amount of time and goods that can be devoted by parents to augmenting the stock of human capital of their children. In the DRC Occupation Sector 1, the Primary sector, is essentially agricultural (Table 1).

\footnotetext{
1 Occupation Sector: The primary sector includes agriculture, livestock, fisheries and forestry. The industry sector includes manufacturing, mining and construction. The commerce sector includes wholesale and retail. Services includes hotels, restaurants, repair services, recreation and tourism, as well as domestic services, utilities, business services, banking and financial services, transportation and telecommunications, and other services.
} 
Table 1: Occupational Sector by Gender and Province in DRC

\begin{tabular}{lllllllll} 
Province & \multicolumn{2}{c}{ Primary sector } & \multicolumn{2}{c}{ Sector of Industry } & \multicolumn{2}{c}{ Sector of Commerce } & \multicolumn{2}{c}{ Sector of Services } \\
& Male & Female & Male & Female & Male & Female & Male & Female \\
Kinshasa & 2.50 & 1.20 & 16.44 & 13.53 & 32.68 & 37.89 & 48.38 & 47.37 \\
Bandundu & 64.81 & 64.88 & 6.86 & 5.88 & 10.39 & 12.30 & 17.94 & 16.93 \\
Bas-Congo & 49.19 & 42.96 & 9.30 & 11.48 & 14.22 & 24.07 & 27.28 & 21.48 \\
Katanga & 46.03 & 45.12 & 19.06 & 16.45 & 15.20 & 23.39 & 19.71 & 15.04 \\
Kasai- Oriental & 60.44 & 64.06 & 6.97 & 4.80 & 14.05 & 18.86 & 18.53 & 12.28 \\
Kasai-occidental & 62.21 & 63.98 & 8.08 & 8.06 & 13.02 & 12.64 & 16.70 & 15.32 \\
Equateur & 67.31 & 54.51 & 6.04 & 7.87 & 13.13 & 24.03 & 13.52 & 13.59 \\
Nord-Kivu & 55.69 & 46.07 & 5.95 & 3.93 & 11.71 & 21.07 & 26.65 & 28.93 \\
Sud-Kivu & 46.07 & 46.86 & 16.39 & 10.33 & 15.82 & 15.87 & 21.72 & 26.94 \\
Maniema & 72.07 & 49.56 & 3.16 & 4.42 & 8.56 & 17.70 & 16.21 & 28.32 \\
Prov. Orientale & 60.13 & 54.01 & 7.93 & 5.47 & 13.35 & 24.09 & 18.60 & 16.42
\end{tabular}

Source: Created by the author based on 1-2-3 data (2012)

Note: A constitutional change to divide the DRC's 11 provinces into 26 was enacted on June 30, 2015.

The industrial sector is still particularly underdeveloped. For example, according to 1-2-3 dataset, more than 55\% of employed people work in the agricultural sector, $16 \%$ work in commerce, $21 \%$ work in services and less than $10 \%$ work in industry. The agricultural sector is equally important for both female and male headed households, although varying significantly across provinces, as shown in table 1 . The structure of the occupational sector differs according to place of residence. For instance, in urban areas, it is the tertiary sector of commerce and services that is higher, accounting for more than two thirds of the jobs, about $83 \%$ in the capital city alone. The industrial sector employs $16 \%$ in the capital city compared to $2 \%$ for the primary sector. In other urbanized areas, the primary sector employs $29 \%$ of the workforce compared to $15 \%$ for the industrial sector. In rural areas, it is obviously agriculture that predominates. This sector utilizes around $82 \%$ of the workforce compared to just over $12 \%$ for the tertiary sector and less than $6 \%$ for the industrial sector (Figure 1).

Figure 1: Occupational Sector by Place of Residence in DRC

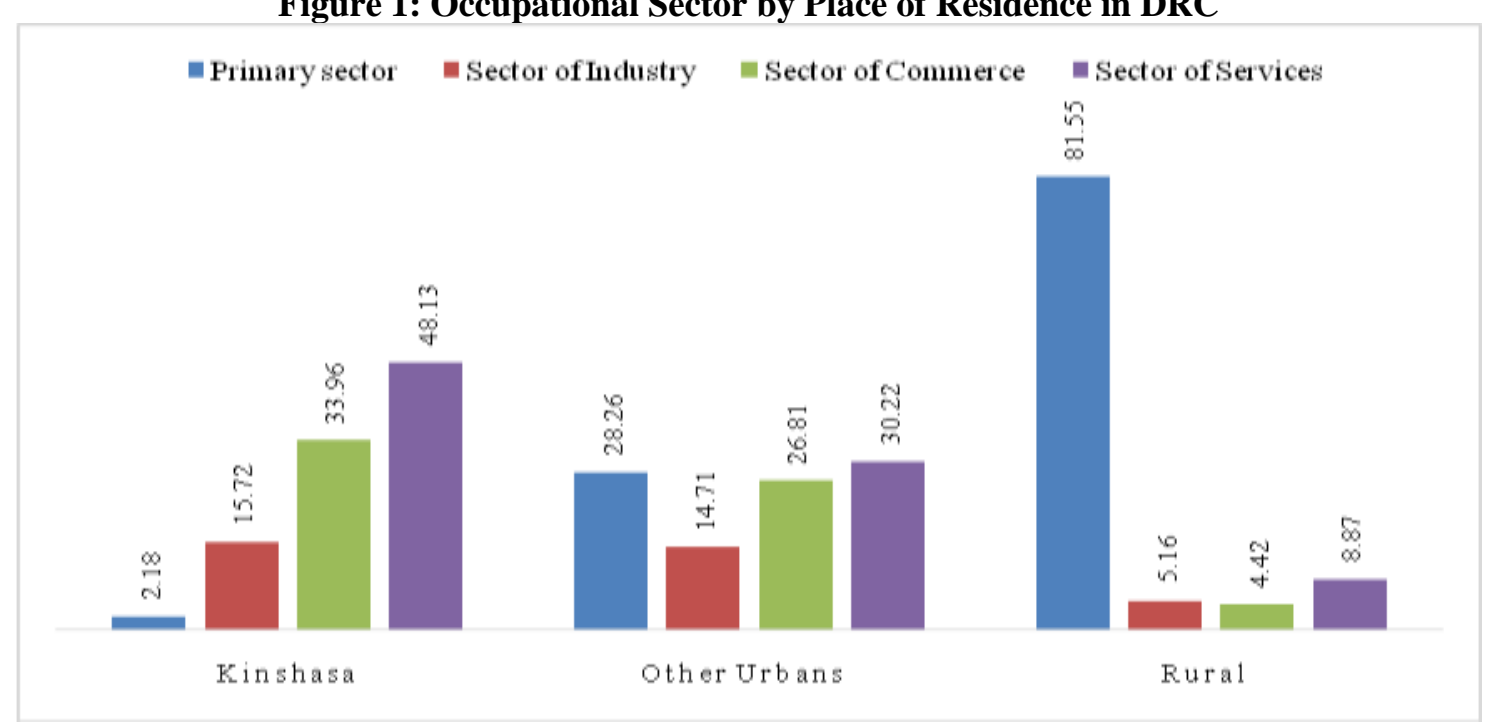

Source: Created by the author based on 1-2-3 data (2012) 
Congolese society is highly patriarchal and dominated by men (Carlsen, 2009). By way of illustration, in DRC, fathers control heritage, schooling and the direction of employment for their children. Traditionally, members of the household are usually kept together under the family father's name, forming a group which is tied to its village or community network. Under such circumstances and as indicated in figure 2, it is likely that children of an agricultural father will inherit their father's attitude to education and work. It is striking however that research on intergenerational mobility has until now been limited mostly to studies of two generations, parents and their children, to the neglect of the effects of grandparents and other extended family members. This study argues that children's fortunes should not be determined by their parents' class position or ability to purchase goods and services that their children need to succeed. However, in order to end the cycle of poverty and promote equal opportunity, we need to understand why, for example, with all things being equal, a child with parents working in agriculture is less likely to succeed than others. What is it that parents in other occupation sectors provide to their children that parents in the agriculture sector often cannot or do not provide? How to end this cycle of poverty is therefore important for policy makers with an interest in kinship system practices and intergenerational social mobility.

Figure 2: Comparison of Current Household Head Working Status with That of Their Father's Generation in DRC.

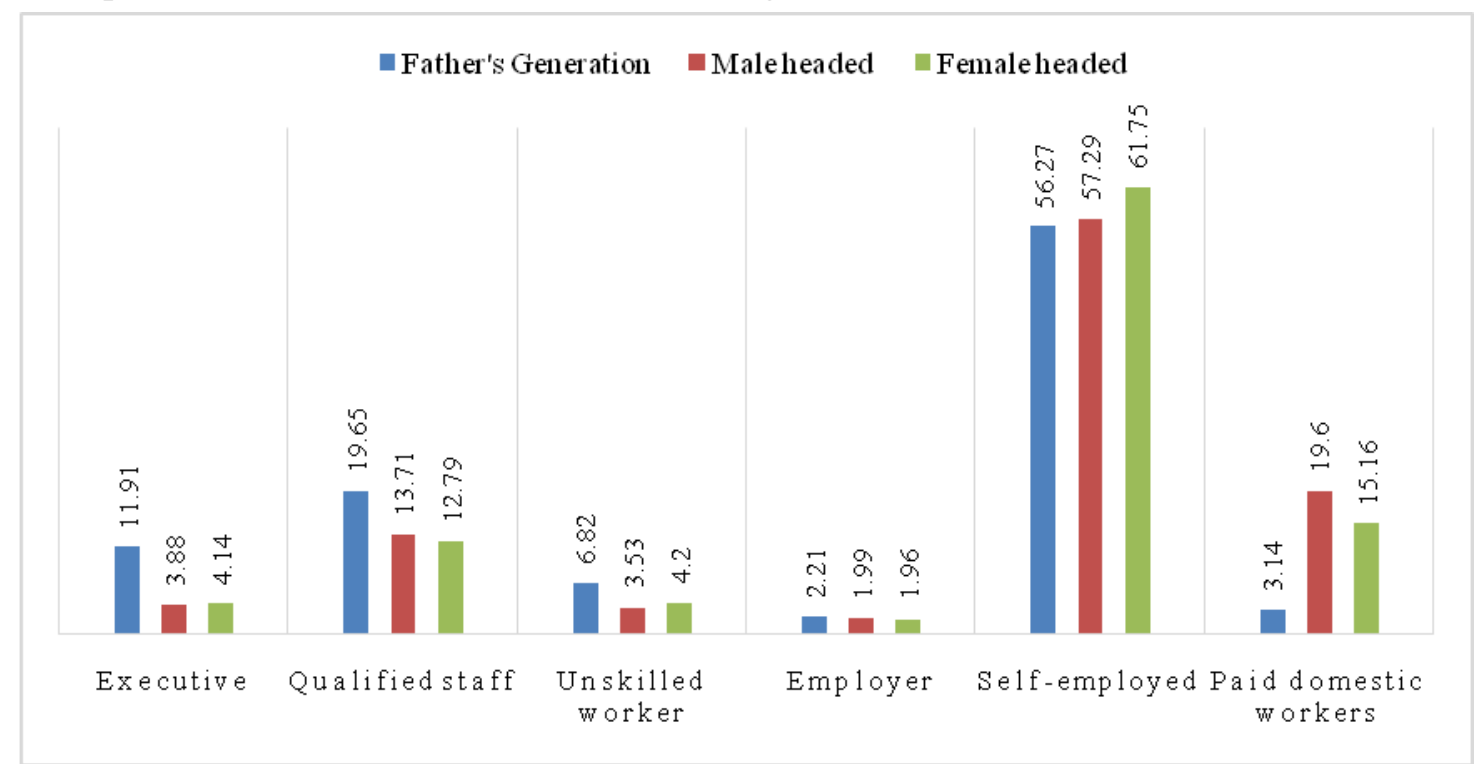

Source: Created by the author based on 1-2-3 data (2012)

\subsection{Education System in the Democratic Republic of Congo}

The country has a 3-6-6 formal education structure with 6 years of compulsory education from age 6 to age 11. There are three years of pre-primary school, which has an official entry age of three, followed by six years of primary school, which has an official entry age of six, followed by six years of secondary education. Since the country's independence in 1960, the education policy has been centered on eradicating illiteracy and providing all children with quality primary and secondary education. However, the outcomes have not always been as successful as expected. Even so, the most striking feature of the education system in the DRC has been its capacity to survive the years of civil war and the harsh conflicts between 1997 and 2007 as well as a series of political and economic instabilities. This long crisis has had devastating effects on all sectors of national life and most importantly on the DRC's education system. Following the low enrollment rates from 2002 to 2008 in both primary and secondary education (Table 2), the government of the DRC adopted a five-year plan for The Development of Primary, Secondary and Vocational Education (2010 - 2015). Despite much progress, the greatest challenge faced by the country's education system is still the important number of out-ofschool children. 
Table 2: Schooling in DRC As Percentage of Schooling Population (2002 to 2016)

Year

Gross enrollment ratio pre-primary

Gross enrollment ratio in Primary school

Net enrollment rate in primary school

Drop-out rate for primary education

Repeaters in primary education

Completion rate for primary education

Pupil-to-teacher ratios in primary

Gross enrollment rate in secondary school
2002

0.86

67.1

35.4

38.2

16.3

41.0

34.3

26
2008

3.2

90.7

45.7

23.9

15.3

57.8

37.3

39.4
2010

3.4

90.8

77.5

45.5

14.1

60.8

37.01

41.2
2012

3.9

101.5

72.1

44.6

11.2

67.8

34.7

43.2
2014

2016

4.18

4.4

108

76.2

75.1

54.7

10.8

13.2

69.8

69.9

35.3

33.2

45.5

46.2

Source: UNESCO Institute for Statistics

The analysis of children's school attendance and parental occupation is particularly meaningful in the context of the DRC since the effect of parental occupation on children's schooling is unclear. This study contributes to the literature by assessing the particular ways in which parental occupation exerts its effects on primary and secondary school-age children in DRC. Although there is a considerable amount of empirical literature on this topic, causal evaluations are still few. A much-debated question is whether parental occupation matters.

Regarding this, Psacharopoulos and Arriagada, (1987) found that parental employment status had a significant positive influence on child school enrollment across gender and age groups in Brazil. By way of contrast, Burney and Irfan, (1995) in their study in Pakistan, found that household labour force participation had a negative effect on child schooling. On the other hand, Assaad et al., (2007) in their study on the effect of child work on children's schooling in Egypt, found that the father's employment sector and status was not an important determinant of child schooling, with few exceptions. Thus, boys 6-14, with fathers employed in the public sector, are more likely to go to school and less likely to work, while girls 15-17 are more likely to work, than those with fathers in irregular private employment. Iddrisu (2014), examining the effect of poverty, household structure and child work on child schooling in Ghana found that the father's occupation did not attain statistical significance in any of the estimations. But Iddrisu's findings also suggested that mothers who work in production related activities are significantly less likely to enroll their children in school than those who work in agriculture.

This paper argues that limiting study to the two-generation paradigm that dominates studies in this field is missing an important aspect. Too little study has been made with respect to the association of grandparents' socioeconomic status with their grandchildren's probability of schooling. Using 1-2-3 survey data on employment, which is the first large nationally representative cross-sectional dataset that includes information on the occupation and education of household heads in DRC, this paper empirically investigates the particular ways in which parental occupation exerts its effects on primary and secondary school-age children in DRC. Through the use of econometrically robust approaches, this study analyzes the drivers behind school attendance and how the role of household head's employment status and its correlates impact the enrollment of children in schools across the DRC. Specifically, this paper estimates the influence of household head's employment status on the probability of children attending school in DRC and importantly, in addition, the effect of the family background of household heads on school participation in DRC.

\section{Empirical Models.}

This study estimates children's school attendance with Linear Probability Model (LPM) for binary response attendance at the individual level as follows:

$\mathrm{P}(\mathrm{y}=1 \mid \mathrm{X})=\beta_{0}+\beta_{1} x_{1}+\beta_{2} x_{2}+\cdots+\beta_{K} x_{K}$

The benefit of using a linear model lies in the fact that it assumes that probability is a linear function of the regressors, while the logistic model assumes that the natural log of the odds is a linear function of the regressors. Additionally, one of the major advantages of using the linear model is its interpretability.

\subsection{Hypothesis}

1. Parental occupation status influences the probability for children's school attendance in DRC (Psacharopoulos \& Arriagada, 1987; Iddrisu 2014). 
2. Family origin of household head, here measured by grandfather's years of education and occupation, has an influence on grandchildren's school attendance in DRC (Zeng and Xie, 2014)

\subsection{Estimating Children's School Attendance by OLS Regression with Cluster Robust Standard Error.}

Using OLS, we regress the school attendance on our explanatory variables with standard errors clustered at district cluster level. The study starts with a simple model to estimate the overall effect of household head occupation status on children's school attendance:

attnd $_{i j}=\alpha_{0}+X_{i} \beta+\beta_{1}$ hhempl $_{j}+\beta_{2}$ Gf_educ $_{j}+\beta_{3}$ Gf_empl $_{j}+\varepsilon_{i j}$

Where attnd is the child's school attendance measure, $\alpha_{0}$ is the constant term. Indices $i$ and $j$ respectively stand for child in household $j \cdot X_{i}$ is the number of control variables X. The explanatory variables of interest are the household head employment status hhempl, household head's father's education $G f_{-} e d u c$ and household head's father's occupation status $G f_{-} e m p l$

\subsection{Data}

This study uses 1-2-3 survey data on employment, which contains repeated-cross sectional and retrospective survey data on the informal sector and household living conditions collected in $2005 \& 2012$. This study uses a unique feature of the 2012 wave. The survey was conducted by the Congolese National Institute for Statistics, in partnership with other actors, including Afristat and the World Bank. The survey is nationally representative and multilayer, covering three nested surveys and three phases involving separate statistical populations. The first wave conducted in 2005 covered approximately 72,685 individuals; 4,444 informal production units, and 3,863 households and the second wave in 2012 covered approximately 111,679 individuals, 8,727 informal production units, and 21,454 households. Both surveys used almost identical questionnaires and followed the same methodology but they do not constitute a panel.

Phase 1 provides detailed information on employment, unemployment, and household and individual sociodemographic characteristics. It includes a household module, an individual questionnaire for individuals aged 5 or above, and a community questionnaire. Phase 2 is a specific survey covering the heads of informal production units. Phase 2 is important as it allows measuring the Congolese informal economy. Phase 3 is a survey on household expenditures that involves interviews among a subsample of the informal production units identified in phase 1 . The present study is interested in empirically investigating the particular ways in which parental occupation exerts its effects on primary and secondary school-age children in the DRC. The sample has been restricted to children of school age, living in the last 12 months, in households surveyed at the time of the interview. The sample is further limited to the school age population 5-17 years old, covering primary school entry and secondary school exit ages in DRC. When reduced the study sample included 33, 557 respondents.

\section{Results}

Table 3 presents summary statistics of the main variables used in this study. Table 4 presents estimates from the regression of children's school attendance on household head occupation. To account for multi-stage cluster sampling, robust standard errors were used. Models 1, 2, 3 and 4, respectively tested the main influence of household head occupation status, income and education on the probability for children's school attendance, taking into account district dummy and place of living from model 2. A negative effect of household head occupation is found in all the four models. Model 1 shows that having an unskilled household head reduces the probability for children's school attendance by 8 percentage point, whereas having a self-employed household head reduces school attendance by 7 percentage points and having a paid domestic household head reduces child school attendance by 9 percentage points. Controlling for the household total consumption in model 3 has little effect on children's probability for school attendance, which is still negatively correlated to any occupation status. However, including both male and female household heads' level of education in model 4, caused the coefficients on parental occupation to lose any significance except for children with unskilled working parents, who are significantly less likely to attend school by 3 percentage points. However, all other variables are still negatively correlated with the probability for children to attend school, apart from qualified staff. All things considered, table 4 also indicates that female children and older male children are less likely to attend school. 
Table 3: Summary statistics of main variables

Variable Definition of variables $\quad$ Obs $\quad$ Mean $\quad$ SD $\quad$ Min Max

Dependent Variables

attnd $\quad 1$ if child is attending school

$\begin{array}{lllll}33,557 & 0.718 & 0.449 & 0 & 1\end{array}$

\section{Child Characteristics}

$\begin{array}{lllllll}\text { age } & \text { Child's age } & 33,557 & 10.965 & 3.379 & 6 & 17 \\ \text { agesq } & \text { Age squared } & 33,557 & 131.674 & 76.662 & 36 & 289 \\ \text { female } & 1 \text { if child's gender is female } & 33,557 & 0.496 & 0.499 & 0 & 1 \\ \text { sibling_boys } & \text { Number of younger sibling boys } & 33,557 & 1.234 & 1.216 & 0 & 6 \\ \text { sibling_girls } & \text { Number of younger sibling girls } & 33,557 & 1.178 & 1.188 & 0 & 10\end{array}$

\section{Household head's occupation status}

Qualified staff $\quad 1$ if qualified staff

$\begin{array}{lllll}33,557 & 0.039 & 0.194 & 0 & 1\end{array}$

Unskilled worker 1 if unskilled worker

$33,557 \quad 0.135 \quad 0.342 \quad 0 \quad 1$

Unskilled worker 1 if unskilled worker

$\begin{array}{lllll}33,557 & 0.036 & 0.187 & 0 & 1\end{array}$

Employer $\quad 1$ if employer

$\begin{array}{lllll}33,557 & 0.019 & 0.139 & 0 & 1\end{array}$

Self-employed $\quad 1$ if self-employed

$33,557 \quad 0.580$

$0.493 \quad 0 \quad 1$

Paid domestic

1 if Paid domestic worker

$33,557 \quad 0.188$

$0.391 \quad 0$

worker

\section{Household head's education}

$\begin{array}{lllllll}\text { mhheduc } & \text { Male headed's years of education } & 33,557 & 3.369 & 3.085 & 0 & 17 \\ \text { fhheduc } & \text { Female headed's years of education } & 33,557 & 3.507 & 3.126 & 0 & 17 \\ \text { hhage } & \text { Household head's age } & 33,557 & 44.328 & 11.695 & 18 & 65 \\ \text { married } & 1 \text { if the head is married } & 33,557 & 0.684 & 0.464 & 0 & 1 \\ \text { hhsize } & \text { Household size } & 33,557 & 7.328 & 2.744 & 1 & 18 \\ \text { nchild } & \text { Number of children in the household } & 33,557 & 3.540 & 2.116 & 0 & 12 \\ \text { fhh } & 1 \text { if household head is female } & 33,557 & 0.162 & 0.368 & 0 & 1 \\ \text { lntotalexp } & \text { Household total consumption } & 33,557 & 63.850 & 4.463 & 49.371 & 82.657 \\ \text { lntotalexp_pc } & \text { Household per capita consumption } & 33,557 & 10.064 & 4.343 & 2.747 & 64.036 \\ \text { Other Control Variables } & & & & & \\ \text { informal } & 1 \text { if employment is in informal sector } & 33,557 & 0.776 & 0.416 & 0 & 1 \\ \text { Nb_units } & \text { Number of production units in area } & 33,557 & 0.441 & 0.831 & 0 & 6 \\ \text { exp } & \text { Household head's years of working experience } & 33,557 & 11.980 & 10.305 & 0 & 40 \\ \text { expsq } & \text { Working experience squared } & 33,557 & 249.716 & 374.43 & 0 & 1600\end{array}$




$\begin{array}{ll}\begin{array}{ll}\text { fathalive } \\ \text { year_prev }\end{array} & \begin{array}{l}1 \text { if father is alive } \\ \text { Household head's years spent in pre } \\ \text { employment }\end{array} \\ \text { two_parent } & 1 \text { if two-parent family } \\ \text { one_parent } & 1 \text { if one-parent family } \\ \text { Variable } & \text { Definition of variables } \\ \text { ext_family } & 1 \text { if extended mono parental family } \\ \text { father } & 1 \text { if father lives in the household } \\ \text { mother } & 1 \text { if mother lives in the household } \\ \text { moremeal } & 1 \text { if child takes three meals a day }\end{array}$

$\begin{array}{lllll}33,557 & 0.468 & 0.498 & 0 & 1 \\ 33,557 & 13.072 & 13.145 & 0 & 45 \\ 33,557 & 0.554 & 0.497 & 0 & 1 \\ 33,557 & 0.086 & 0.280 & 0 & 1 \\ \text { Obs } & \text { Mean } & \text { SD } & \text { Min } & \text { Max } \\ 33,557 & 0.356 & 0.479 & 0 & 1 \\ 33,557 & 0.739 & 0.438 & 0 & 1 \\ 33,557 & 0.828 & 0.377 & 0 & 1 \\ 33,557 & 0.160 & 0.366 & 0 & 1\end{array}$

\section{Grandfather 'Occupation status}

\begin{tabular}{|c|c|c|c|c|c|c|}
\hline Executive & 1 if executive & 33,557 & 0.046 & 0.210 & 0 & 1 \\
\hline Qualified staff & 1 if qualified staff & 33,557 & 0.116 & 0.320 & 0 & 1 \\
\hline Unskilled worker & 1 if unskilled worker & 33,557 & 0.068 & 0.252 & 0 & 1 \\
\hline Employer & 1 if employer & 33,557 & 0.022 & 0.146 & 0 & 1 \\
\hline Self-employed & 1 if self-employed & 33,557 & 0.562 & 0.496 & 0 & 1 \\
\hline Paid domestic & 1 if paid domestic workers & 33,557 & 0.025 & 0.159 & 0 & 1 \\
\hline \multicolumn{7}{|c|}{ Grandfather 'year of education } \\
\hline granpas_educ & Grandfather's years of schooling & 33,557 & 5.773 & 5.193 & 0 & 18 \\
\hline \multicolumn{7}{|c|}{ Area Characteristics } \\
\hline rural & 1 if rural household & 33,557 & 0.516 & 0.499 & 0 & 1 \\
\hline district & District dummy & 33,557 & 13.464 & 8.002 & 1 & 26 \\
\hline \multicolumn{7}{|c|}{ Parents school satisfaction survey } \\
\hline Sch_teaching & 1 if satisfied with teaching quality & 33,557 & 0.818 & 0.385 & 0 & 1 \\
\hline Sch_Nbstudent & 1 if satisfied with number of students & 33,557 & 0.744 & 0.435 & 0 & 1 \\
\hline Sch_building & 1 if satisfied with school building & 33,557 & 0.588 & 0.492 & 0 & 1 \\
\hline Sch_toilet & 1 if satisfied with school toilet & 33,557 & 0.485 & 0.499 & 0 & 1 \\
\hline \multicolumn{7}{|l|}{ School Type } \\
\hline public & 1 if public school & 33,557 & 0.259 & 0.438 & 0 & 1 \\
\hline denominational & 1 if denominational school & 33,557 & 0.610 & 0.487 & 0 & 1 \\
\hline private & 1 if private school & 33,557 & 0.129 & 0.336 & 0 & 1 \\
\hline
\end{tabular}

Table 5 presents estimates from the regression of children's school attendance on household head's occupation, including more household characteristic variables. Models 5 to 8 , including both younger (boys \& girls) sibling variables, significantly reduces the probability for school attendance in every single model. 
In model 6, including household size does not have an effect on school attendance, whereas household head's age, marital status, female headed household, having a father and mother alive or having both parents at home, significantly increase the probability for school attendance. However, these variables do not alter the sign and significance of household head occupation status. When controlling for household head's years of experience in model 8 , it significantly increases the probability for children with qualified staff heads to attend school by 2.4 percentage points.

Table 4: Regression of school attendance on Parental's Occupation, Income and Education with other child characteristics.

School attendance

Household head's

Model2

Full Sample

occupation

Model 1

Model3

Model4

Executive (Base category)

Qualified staff

$-0.0120$

$-0.0065$

$-0.0047$

0.0137

(0.0117)

(0.0116)

(0.0116)

(0.0111)

Unskilled worker

$-0.0837 * * *$

$-0.0659 * * *$

$-0.0618 * * *$

$-0.0315^{*}$

(0.0149)

(0.0148)

(0.0148)

$(0.0142)$

Employer

$-0.0278$

$-0.0127$

$-0.0114$

0.0037

(0.0177)

(0.0177)

(0.0169)

Self-employed

$-0.0698 * * *$

$-0.0578 * * *$

$-0.0514 * * *$

$-0.0173$

(0.0108)

(0.0108)

(0.0104)

Paid domestic

$-0.0899 * * *$

$-0.0598 * * *$

$-0.0530 * * *$

$-0.0153$

(0.0113)

(0.0116)

(0.0117)

(0.0112)

Household total consumption

Intotalexp

$0.0050 * * *$

$0.0030^{* * * *}$

(0.0006)

(0.0006)

Household head education

mhheduc

$0.0293 * * *$

$(0.0008)$

fhheduc

$0.0062 * * *$

(0.0007)

\section{Child Characteristics}

age

$0.1423 * * *$

(0.0042)

agesq

$-0.0066 * * *$

(0.0002)

female

$-0.0237 * * *$

Area Characteristics

rural

$-0.0663 * * *$

(0.0039)

District dummy

(0.0046)

Yes

Constant

$0.8929 * * *$

0.8836 ***

$-0.0446 * * *$

$-0.0237 * * *$

(0.0054)

(0.0052)

Yes

Yes

$\begin{array}{ll} & (0.0103) \\ \mathrm{N} & 33557 \\ \mathrm{r} 2 \mathrm{a} & 0.0049\end{array}$

(0.0118)

$0.5326 * * *$

$-0.2007 * * *$

33557

(0.0456)

(0.0492)

0.0271

33557

33557

0.1081

Standard errors in parentheses. * significant at 10\%; ** significant at 5\%, *** significant at $1 \%$. 
Table 5: Regression of School Attendance on Parental' s Occupation, including other household variables. Model $5 \quad$ Model $6 \quad$ Model $7 \quad$ Model $8 \quad$ Model $9 \quad$ Model 10

\section{Household head's occupation}

Executive (Base category)

Qualified staff

$\begin{array}{cc}0.0138 & 0.0150 \\ (0.0111) & (0.0111)\end{array}$

0.1180

$0.0239 *$

$0.0256^{*}$

$0.0301 * *$

Unskilled worker

$-0.0327 *$

$-0.0307^{*}$

(0.0111)

(0.0111)

(0.0111)

(0.0112)

(0.0142)

(0.0141)

$-0.0159$

$-0.0052$

$-0.0007$

0.0055

$0.0013 \quad 0.0045$

(0.0143)

(0.0143)

(0.0143)

(0.0145)

Employer

(0.0169)

0.0239

0.0253

0.0279

0.0293

$-0.0168)$

(0.0171)

(0.0171)

(0.0171)

(0.0172)

Self-employed

$\begin{array}{ll}-0.0167 & -0.0158 \\ (0.0103) & (0.0103)\end{array}$

0.0031

0.0050

0.0080

0.0129

$-0.0169 \quad-0.0167$

(0.0108)

(0.0108)

(0.0108)

(0.0108)

Paid domestic

$(0.0112)$

(0.0112)

0.0025

0.0110

0.0139

0.0193

(0.0116)

(0.0116)

(0.0116)

(0.0117)

\section{Household total consumption}

lntotalexp

$\begin{array}{llllll}0.0026 * * * & 0.0024 * * * & 0.0022 * * * & 0.0024 * * * & 0.0022 * * * & 0.0021 * * * \\ (0.0006) & (0.0006) & (0.0006) & (0.0006) & (0.0006) & (0.0006)\end{array}$

\section{Household head's education}

mhheduc

$0.0292 * * *$

$0.0287 * * *$

$0.0284 * * *$

$0.0283 * * *$

$0.0278^{* * * *}$

$0.0275^{* * * *}$

$(0.0008)$

$(0.0008)$

(0.0008)

(0.0008)

(0.0008)

(0.0008)

fhheduc

$\begin{array}{ll}0.0061 * * * & 0.0061 * * * \\ (0.0006) & (0.0006)\end{array}$

$0.0061 * * *$

$0.0060^{* * * *}$

$0.0059 * * *$

$0.0058 * * *$

(0.0006) (0.0006)

(0.0006)

(0.0006)

(0.0006)

(0.0006)

\section{Child Characteristics}

\begin{tabular}{|c|c|c|c|c|c|c|}
\hline age & $\begin{array}{l}0.1427 * * * \\
(0.0043)\end{array}$ & $\begin{array}{l}0.1430^{* * *} \\
(0.0042)\end{array}$ & $\begin{array}{l}0.1431 * * * \\
(0.0042)\end{array}$ & $\begin{array}{l}0.1426^{* * *} \\
(0.0042)\end{array}$ & $\begin{array}{l}0.1441^{* * *} \\
(0.0042)\end{array}$ & $\begin{array}{l}0.1429 * * * \\
(0.0042)\end{array}$ \\
\hline agesq & $\begin{array}{l}-0.0065^{* * *} \\
(0.0002)\end{array}$ & $\begin{array}{l}-0.0065 * * * \\
(0.0002)\end{array}$ & $\begin{array}{l}-0.0065 * * * \\
(0.0002)\end{array}$ & $\begin{array}{l}-0.0064 * * * \\
(0.0002)\end{array}$ & $\begin{array}{l}-0.0065^{* * * *} \\
(0.0002)\end{array}$ & $\begin{array}{l}-0.0064 * * * \\
(0.0002)\end{array}$ \\
\hline female & $\begin{array}{l}-0.0231 * * * \\
(0.0039)\end{array}$ & $\begin{array}{l}-0.0219 * * * \\
(0.0039)\end{array}$ & $\begin{array}{l}-0.0221 * * * \\
(0.0039)\end{array}$ & $\begin{array}{l}-0.0214 * * * \\
(0.0039)\end{array}$ & $\begin{array}{l}-0.0215^{* * *} \\
(0.0039)\end{array}$ & $\begin{array}{l}-0.0211 * * * \\
(0.0038)\end{array}$ \\
\hline nchild & $\begin{array}{l}0.0161 * * * \\
(0.0017)\end{array}$ & $\begin{array}{l}0.0162 * * * \\
(0.0025)\end{array}$ & $\begin{array}{l}0.0167 * * * \\
(0.0025)\end{array}$ & $\begin{array}{l}0.0164 * * * \\
(0.0025)\end{array}$ & $\begin{array}{l}0.0163 * * * \\
(0.0025)\end{array}$ & $\begin{array}{l}0.0174 * * * \\
(0.0025)\end{array}$ \\
\hline younger_sibling (boys) & $\begin{array}{l}-0.0086^{* * *} \\
(0.0024)\end{array}$ & $\begin{array}{l}-0.0112 * * * \\
(0.0025)\end{array}$ & $\begin{array}{l}-0.0109 * * * \\
(0.0025)\end{array}$ & $\begin{array}{l}-0.0109 * * * \\
(0.0025)\end{array}$ & $\begin{array}{l}-0.0105^{* * *} \\
(0.0025)\end{array}$ & $\begin{array}{l}-0.0111 * * * \\
(0.0025)\end{array}$ \\
\hline younger_sibling (girls) & $\begin{array}{l}-0.0081 * * * \\
(0.0024)\end{array}$ & $\begin{array}{l}-0.0103 * * * \\
(0.0025)\end{array}$ & $\begin{array}{l}-0.0099 * * * \\
(0.0025)\end{array}$ & $\begin{array}{l}-0.0096 * * * \\
(0.0025)\end{array}$ & $\begin{array}{l}-0.0091 * * * \\
(0.0025)\end{array}$ & $\begin{array}{l}-0.0097 * * * \\
(0.0025)\end{array}$ \\
\hline \multicolumn{7}{|c|}{ Household Characteristics } \\
\hline hhsize & & $\begin{array}{c}0.0003 \\
(0.0015)\end{array}$ & $\begin{array}{l}-0.0006 \\
(0.0015)\end{array}$ & $\begin{array}{l}-0.0005 \\
(0.0015)\end{array}$ & $\begin{array}{l}-0.0009 \\
(0.0015)\end{array}$ & $\begin{array}{l}-0.0023 \\
(0.0016)\end{array}$ \\
\hline hhage & & $\begin{array}{c}0.0004 * \\
(0.0002)\end{array}$ & $\begin{array}{l}0.0004^{*} \\
(0.0002)\end{array}$ & $\begin{array}{l}0.0001 \\
(0.0002)\end{array}$ & $\begin{array}{c}0.0002 \\
(0.0002)\end{array}$ & $\begin{array}{l}0.0002 \\
(0.0002)\end{array}$ \\
\hline
\end{tabular}




\begin{tabular}{|c|c|c|c|c|c|}
\hline married & $\begin{array}{l}0.0180 * * * \\
(0.0050)\end{array}$ & $\begin{array}{l}0.0177 * * * \\
(0.0050)\end{array}$ & $\begin{array}{l}0.0171 * * * \\
(0.0050)\end{array}$ & $\begin{array}{l}0.0171 * * * \\
(0.0050)\end{array}$ & $\begin{array}{l}0.0222 * * * \\
(0.0051)\end{array}$ \\
\hline fhh & $\begin{array}{l}0.0449 * * * \\
(0.0085)\end{array}$ & $\begin{array}{l}0.0485 * * * \\
(0.0085)\end{array}$ & $\begin{array}{l}0.0496 \text { *** } \\
(0.0085)\end{array}$ & $\begin{array}{l}0.0483^{* * *} \\
(0.0085)\end{array}$ & $\begin{array}{l}0.0301 * * * \\
(0.0089)\end{array}$ \\
\hline fathalive & $\begin{array}{l}0.0179 * * * \\
(0.0041)\end{array}$ & $\begin{array}{l}0.0169 * * * \\
(0.0041)\end{array}$ & $\begin{array}{l}0.0179 * * * \\
(0.0041)\end{array}$ & $\begin{array}{l}0.0171 \text { *** } \\
(0.0041)\end{array}$ & $\begin{array}{l}0.0176 * * * \\
(0.0041)\end{array}$ \\
\hline father at home & $\begin{array}{l}0.0572 * * * \\
(0.0076)\end{array}$ & $\begin{array}{l}0.0572 * * * \\
(0.0076)\end{array}$ & $\begin{array}{l}0.0561 * * * \\
(0.0076)\end{array}$ & $\begin{array}{l}0.0550^{* * * *} \\
(0.0076)\end{array}$ & $\begin{array}{l}0.0664 * * * \\
(0.0079)\end{array}$ \\
\hline mother at home & $\begin{array}{l}0.0359 * * * \\
(0.0065)\end{array}$ & $\begin{array}{l}0.0368 * * * \\
(0.0065)\end{array}$ & $\begin{array}{l}0.0351 * * * \\
(0.0065)\end{array}$ & $\begin{array}{l}0.0344 * * * \\
(0.0065)\end{array}$ & $\begin{array}{l}0.0335^{* * *} \\
(0.0067)\end{array}$ \\
\hline moremeal & $\begin{array}{c}-0.0142 * * \\
(0.0054)\end{array}$ & $\begin{array}{l}-0.0139 * * \\
(0.0054)\end{array}$ & $\begin{array}{l}-0.0144 * * \\
(0.0054)\end{array}$ & $\begin{array}{c}-0.0150 * * \\
(0.0054)\end{array}$ & $\begin{array}{c}-0.0151 * * \\
(0.0054)\end{array}$ \\
\hline \multicolumn{6}{|c|}{ Other control variables } \\
\hline informal sector & & $\begin{array}{l}-0.0373 * * * \\
(0.0055)\end{array}$ & $\begin{array}{l}-0.0386 * * * \\
(0.0055)\end{array}$ & $\begin{array}{l}-0.0355^{* * *} \\
(0.0055)\end{array}$ & $\begin{array}{l}-0.0339 * * * \\
(0.0055)\end{array}$ \\
\hline $\mathrm{Nb \_ units}$ & & $\begin{array}{c}0.0048 \\
(0.0026)\end{array}$ & $\begin{array}{l}0.0072 * * \\
(0.0026)\end{array}$ & $\begin{array}{l}0.0069 * * \\
(0.0026)\end{array}$ & $\begin{array}{l}0.0067 * * \\
(0.0026)\end{array}$ \\
\hline $\exp$ & & & $\begin{array}{l}0.0042 * * * \\
(0.0006)\end{array}$ & $\begin{array}{l}0.0043^{* * * *} \\
(0.0006)\end{array}$ & $\begin{array}{l}0.0044 * * * \\
(0.0006)\end{array}$ \\
\hline expsq & & & $\begin{array}{l}-0.0001 * * * \\
(0.0000)\end{array}$ & $\begin{array}{l}-0.0001 * * * \\
(0.0000)\end{array}$ & $\begin{array}{l}-0.0001 * * * \\
(0.0000)\end{array}$ \\
\hline year_prev & & & $\begin{array}{c}0.0003 \\
(0.0002)\end{array}$ & $\begin{array}{c}0.0003 * \\
(0.0002)\end{array}$ & $\begin{array}{l}0.0003 \\
(0.0002)\end{array}$ \\
\hline
\end{tabular}

\section{Living Arrangement}

$0.2604 * * *$ (0.0384)

one_parent

ext_family

$0.3159 * * *$ (0.0390)

$0.2842 * * *$ (0.0384)

Grandfather's education

granpa_educ

$$
\begin{array}{ll}
0.0028 * * * & 0.0027 * * * \\
(0.0004) & (0.0004)
\end{array}
$$

\section{Grandfather's occupation} status

Executive (Base category)

Qualified staff

Unskilled worker 
Self-employed

$-0.0167 *$

$(0.0069)$

Paid domestic

$-0.0120$

$(0.0128)$

\section{Household head's school satisfaction survey}

Sch_Nbstudent

$0.0206 * * *$

(0.0046)

Sch_toilet

$-0.0097 *$

$(0.0042)$

\section{School Type}

Public school (Base category)

denominational

0.0079

$(0.0045)$

private

$0.0190 * *$

(0.0069)

\section{Area Characteristics}

$\begin{array}{lllllll}\text { rural } & -0.0239 * * * & -0.0270^{* * *} & -0.0219 * * * & -0.0269 * * * & -0.0239 * * * & -0.0238^{* * * *} \\ & (0.0052) & (0.0052) & (0.0054) & (0.0054) & (0.0054) & (0.0055) \\ \text { District dummy } & \text { Yes } & \text { Yes } & \text { Yes } & \text { Yes } & \text { Yes } & \text { Yes } \\ \text { Constant } & -0.2188^{* * *} & -0.3305^{* * *} & -0.3032 * * * & -0.3322^{* * *} & -0.3524 * * * & -0.6245^{* * * *} \\ & (0.0492) & (0.0501) & (0.0502) & (0.0504) & (0.0504) & (0.0625) \\ \mathrm{N} & 33557 & 33557 & 33557 & 33557 & 33557 & 33557 \\ \text { r2a } & 0.1117 & 0.1180 & 0.1192 & 0.1210 & 0.1222 & 0.1254\end{array}$

Standard errors in parentheses. * significant at 10\%; ** significant at 5\%, *** significant at $1 \%$.

The main results of this study are displayed in Models 9 and 10, which estimate the overall effect of grandparents' education and occupation status on grandchildren's school attendance. All else being equal, having an educated grandparent increases the probability for grandchildren's school attendance by 0.3 percentage points. Although statistically significant, this effect is not large. However, including grandfather's years of education and occupation in model 10, removes every negative sign associated with their grandchildren's school attendance in DRC. Additionally, an educated grandfather changes the sign and significance of the household heads occupation status variable. Therefore, a grandchild with a qualified-staff working father from a family where the grandfather was educated is more likely to attend school by 3.2 percentage points. Note that the coefficient of grandfather's education is almost the same in model 10 when estimated with grandfather's occupation status. However, grandchildren from households with qualified-staff grandparents or self-employed grandparents are significantly less likely to attend school in DRC.

\section{Discussion and Conclusion}

How does household head occupation status influence children's school attendance in DRC? Our analysis shows that parental occupation matters in DRC. The most remarkable correlation is with household head's working experience and children's school attendance. In reality, there are gaps not only in terms of parental occupation status but also according to parental year of working experience and that may show the influence of preexisting differences in families' characteristics. According to Lefebvre et al. (1998), these factors, which predispose parents towards employment, may be the real reason for the better schooling of children. That is to say, it is plausible that work experiences positively affect resources such as innate or learned skills, educational attainment, psychological and health status, personal or psychological resources such as resiliency, positive outlook, motivation, and social capital. These parental 28 
characteristics are resources used by parents for the socialization process of children and the provision of cognitive stimulation. These resources include cultural values inherited from the parents' own family of origin and life experiences. Interestingly, our analysis also indicates that parental occupation matters in DRC, and the influence is contingent upon persistence in education and occupation across family generations. Previous research has found that grandparents do not exert significant direct influences on grandchildren's schooling, as their influences are completely mediated through the middle generation (Bol and Kalmijn, 2015; Moulton et al., 2017; Lehti et al., 2018).

However, it is noted that most of the research has been done in western societies and there is insufficient evidence to draw any conclusions about whether the effect of grandparents' occupation on grandchildren's schooling varies across countries (Zeng and Xie, 2014). In DRC, grandfather's education and occupation directly influenced their grandchildren's school attendance after controlling for parents' characteristics. The effect of grandfather's education and occupation is significant on grandchildren's schooling. The findings from this study also indicate a strong correlation of social mobility between generations in DRC. In fact, the results indicate a higher likelihood for a household head to work in the same industry as their father in DRC. The same observation can be made on all other sectors. Over 50\% of household heads are in the same sector of activity as their father (Figures 2). Further work needs to be carried out to establish whether social mobility, which consists of quantifying and understanding the mechanisms of transmission of social status from one generation to the next, is the moderator of schooling in the DRC (Mare and Song, 2014).

\section{Acknowledgements}

I am grateful to Professor Keiichi Ogawa, Professor Yasuharu Shimamura and Professor Minato Nakazawa for their guidance. I wish to thank two anonymous referees and I am also thankful to Michael Shackleton for useful discussion.

\section{References}

Ali Shah, A, M and Anwar, M (2014). Impact of Parent's Occupation and Family Income on Children's Performance. International Journal of Research (IJR) Vol-1, Issue-9, October 2014 ISSN 2348-6848.

Al-Samarrai, S and Peasgood, T (1998) Educational Attainments and Household Characteristics in Tanzania, Economics of Education Review, 17 (4) 1998.

Al-Samarrai, S and Reilly, B (2000) Urban and Rural Differences in Primary School Attendance: An Empirical Study for Tanzania, Journal of African Economies, 9 (4), 2000.

Assad, R., Deborah, L., and Zibani, N. (2001) The Effect of Child Work on School in Egypt. A Paper Presented at The Workshop on Poverty and Its Determinants in The Middle East, Sanaa, Yemen.

Assaad, R; Levison, D; Zibani, N. (2007). The Effect of Child Work on Schooling: Evidence from Egypt. Minnesota Population Center, Working Paper.

Burney, A. N. \& Irfan, M. (1995). Determinants of child school enrolment: evidence from LDC's using choice theoretic approach. International Journal of Social Economics, Vol. 22, No. 1, pp. 24-40.

Becker, S, G (1965) A Theory of the allocation of time. Economic Journal 75(299), Pp. 493-517.

Becker, S, G (1993) A Treatise on the Family_ Enlarged Edition-Harvard University Press.

Beegle, K and Burke, K (2004) Why Children Aren't Attending School: The Case of North-western Tanzania, Journal of African Economies, 13 (2)

Berniell, L (2017) Occupational Choice and Investments in Human Capital in Informal Economies. CAF Working paper $\mathrm{N}^{\circ}$ 2017/27

Birdsall, N \& Orivel, F (2006) Demand for Primary Schooling in Rural Mali: Should User Fees be Increased? Pp. 279-296 | Published online: 28 Jul 2006.

Blake, J (1986) Number of siblings, family background, and the process of educational attainment, Social Biology, 33:1-2, 521, DOI: $10.1080 / 19485565.1986 .9988618$.

Bol, T and Kalmijn, M. (2015). Grandparents' resources and grandchildren's schooling: Does grandparental involvement moderate the grandparent effect? Social Science Research, 55, Pp. 155-170.

Carlsen, E (2009) Ra/pe and War in the Democratic Republic of the Congo,Peace Review, 21 (4), Pp. 474-483, DOI: $10.1080 / 10402650903323546$.

Democratic Republic of Congo Survey on Out-of-School-Children (2013) Organized by the Ministry of Primary, Secondary and Vocational Education.

DHS (2007) Congo Democratic Republic 2007 DHS Final Report (French). Retrieved from https://dhsprogram.com/what-we-do/survey/survey-display-239.cfm

DHS (2014) Congo Democratic Republic 2013-2014 DHS Final Report (French). Retrieved from https://dhsprogram.com/what-we-do/survey/survey-display-239.cfm

DRC Plan for The Development of Primary, Secondary and Vocational Education (2010 - 2016). Translated from French on January 31, 2019. 
DRC Education Sector Plan 2014-2024. Retrieved from https://www.globalpartnership.org/country/democratic-republic-congo.

EFA (1990) World Conference on Education for All. Retrieved from http://www.un.org/en/development/devagenda/education.shtml. Accessed on December 23, 2018.

FHI360 (2018) Education System in the Democratic Republic of the Congo. Retrieved from https://www.epdc.org/country/congodemrep. Accessed on September 13,2018.

Francavilla, F; Giannelli, C, G; Grilli, L (2013) Mothers' Employment and their Children's Schooling: A Joint Multilevel Analysis for India. World Development Vol. 41, Pp. 183-195.

Hart, K (1973) Informal Income Opportunities and Urban Employment in Ghana. The Journal of Modern African Studies, 11 (1)

Heckman, J. J (1976) The common structure of statistical models of truncation, sample selection and limited dependent variables and a simple estimator for such models. Annals of Econometrics and Social Measurement 5, Pp. 475-492.

Heckman, J. J (1979) Sample selection bias as a specification error. Econometrica 47, Pp. 153-161.

Hedges, S; Mulder, B, M; James, S; Lawson, W, D (2016) Sending children to school: rural livelihoods and parental investment in education in northern Tanzania. Evolution and Human Behavior 37, Pp. 142-151

Hellevik, O. (2007) Linear versus logistic regression when the dependent variable is a dichotomy. Quality \& Quantity, 43(1), 59-74. http://doi.org/10.1007/s11135-007-9077-3.

Herdt, D, T., Poncelet, M (2010) Stakes and actors around the reduction of school fees in the DRC: final report translated from French "Enjeux et acteurs autour de la réduction des frais scolaires en RDC: rapport final", s.l., DFID.

Herdt, D, T; Voet, M, W and Girwa, M, F (2015) Analysis of the situation of children and women in the DRC. Retrieved from https://www.unicef.org/drcongo/french/Rapport_SITAN_RDC_2015_VF.pdf.

Hermida, P (2014) Who Benefits from the Elimination of School Enrolment Fees? Evidence from Ecuador. Desarrollo y Sociedad, (74), 69-132. https://dx.doi.org/10.13043/DYS.74.2.

Hirano, K., and G. W. Imbens (2004) The propensity score with continuous treatments. In Applied Bayesian Modeling and Causal Inference from Incomplete-Data Perspectives, ed. A. Gelman and X.-L. Meng, 73-84. West Sussex, England: Wiley InterScience.

Iddrisu, M, A (2014) The Effect of Poverty, Household Structure and Child Work on School Enrolment. Journal of Education and Practice, 5 (6). Www.iiste.org ISSN 2222-1735 (Paper) ISSN 2222-288X (Online)

ILO (1993) Resolution Concerning the International Classification of Status in Employment (ICSE), adopted by the Fifteenth International Conference of Labor Statisticians", in: Fifteenth International Conference of Labor Statisticians (Geneva,19-28 January 1993), Report of the Conference (Geneva, ILO).

ILO/IPEC-SIMPOC (2007) Explaining the Demand and Supply of Child Labour: A Review of The Underlying Theories.

IMF (2013) Democratic Republic of the Congo: Poverty Reduction Strategy Paper.

IMF (2015) Democratic Republic of The Congo. IMF Country Report No. 15/281.

Lefebvre, P and Merrigan, P. (1998). Family Background, Family Income, Maternal Work and Child Development. CREFÉ, Université du Québec à Montréal, Working Paper 78.

Lehti, H ; Erola, J ; Tanskanen, A. (2019). Tying the Extended Family Knot—Grandparents' Influence on Educational Achievement, European Sociological Review, 35(1), Pp.29-48.

Leibowitz, A. (1977). Parental Inputs and Children's Achievement. The Journal of Human Resources, 12, (2), Pp. $242-251$.

Lin, H, H (2018) Number of siblings and educational attainment: application of son preference, Applied Economics Letters, 25:2, 83-86, DOI:10.1080/13504851.2017.1296543.

Mare, D, R and Song, X. (2014). Social Mobility in Multiple Generations. California Center for Population Research OnLine Working Paper Series.

Mayer, S. E. (2002). The influence of parental income on children's outcomes. Wellington, New Zealand: Knowledge Management Group, Ministry of Social Development.

Mohammed, T (2014) Factors Affecting Pupils' Participation in Basic Education: Evidence from Ghana. The International Journal of Humanities \& Social Studies (ISSN 2321 - 9203).

Moulton, V; Flouri, E; Joshi, H; and Sullivan, A. (2017) The influence of grandparents' social class on children's aspirations, British Journal of Sociology of Education, 38:4, 500-517, DOI: 10.1080/01425692.2015.1093407.

O'Doherty, M (2018) Healing the Congo - Improving Human Rights, Social Cohesion and Education in the Democratic Republic of the Congo.

Oketch, M (2019) Access, Poverty and Learning Achievement for Primary School Leavers in Kenya: Analysis of Evidence from 47 Counties. Journal of Comparative and International Education, 49(1) Pp.1-15

Patrinos, H and Psacharopoulos, G (1997) Family Size, Schooling and Child Labor in Peru, Journal of Population Economics, 10, Pp. 387-405.

Psacharopoulos, G. \& Arriagada, A. M. (1987). School Participation, Grade Attainment and Literacy in Brazil: A 1980 Census Analysis. Discussion Paper No. EDT86.

Psacharopoulos, G (1997) Child Labor versus Educational Attainment: Some Evidence from Latin America, Journal of Population Economics, 10, Pp. 377-86. 
Post, D. (2011) Constitutional Reform and the Opportunity for Higher Education Access in Ecuador Since 1950. Education Policy Analysis Archives, 19 (20). Retrieved on 3rd November 2018, from http://epaa.asu.edu/ojs/article/view/814.

Raffo, C. et al (2007) Education and poverty: A critical review of theory, policy and practice. York: JRF.

Raja, K, B \& Burnett, N, R (2004) User fees in primary education (English). Education for All working papers. Washington, DC: World Bank. http://documents.worldbank.org/curated/en/584751468779390222/User-fees-in-primaryeducation.

SGDs (2018) Report of the Secretary-General, "Progress towards the Sustainable Development Goals", E/2017/66. Retrieved from https://sustainabledevelopment.un.org/sdg4.

Shimamura, Y \& Carter, M (2015) The Dynamics of Educational Attainment for Orphaned Children in Sub-Saharan Africa: Evidence from Malawi. Journal of international cooperation studies 23(2), Pp. 29-61, 2016-01.

Soares, R., Kruger, D., \& Berthelon, M (2012) Household Choices of Child Labor and Schooling: A Simple Model with Application to Brazil. The Journal of Human Resources, 47(1), 1-31. Retrieved from http://www.jstor.org/stable/23214380

Tien, N. D. L. (2014) An analysis of labour market returns to education in Vietnam: Evidence from the National Labour Force Survey 2012". Turin School of Development Working Paper, No. 3, International Training Centre of the ILO, Turin, Italy.

Tumen, S (2015) Skill Acquisition in the Informal Economy and Schooling Decisions: Evidence from Emerging Economies. Online at http://mpra.ub.uni-muenchen.de/62909/.

UN (2017) Report of the Secretary-General, "Progress towards the Sustainable Development Goals", E/2017/66. Retrieved from https://sustainabledevelopment.un.org/sdg4.

UNDP (2018) Human Development Reports. Retrieved from http://hdr.undp.org/en/content/human-development-index-hdi. Accessed on September 16, 2018.

UNICEF and UNESCO-UIS (2011), Global initiative on out-of-school children: Conceptual and methodological framework (CMF). New York and Montreal: UNICEF and UIS.

UNICEF (2013), National Survey on the situation of out-of-school children and adolescents in The Democratic Republic of Congo. Global initiative on out-of-school children.

UNESCO (2018) Educational Attainment as defined in its website. http://uis.unesco.org/en/topic/educational-attainment. Accessed on 6 September,2018.

UNHCR (2018) Democratic Republic of the Congo. Retrieved from http://www.unhcr.org/democratic-republic-of-thecongo.html. Accessed on September 16, 2018.

Usaini, I, M and Abubakar, B, N (2015). The Impact of Parents' Occupation on Academic Performance of Secondary School Students in Kuala Terengganu. Multilingual Academic Journal of Education and Social Sciences, 3, (1) ISSN: 23080876.

Wooldridge, M, J (2011) Econometric Analysis of Cross Section and Panel Data, second edition. The MIT Press.

World Bank (1995). Priorities and Strategies for Education: A World Bank Sector Review, Education and Social Policy Department, The World Bank.

World Bank (2006) Implementation of free basic education policy. The Education Working Paper Series produced by the Education Unit at the World Bank (HDNED).

World Bank (2012) Congo, Democratic Republic of - Support to Education Program under the Global Partnership for Education Fund Project.

World Bank (2015) Public Expenditure Review of The Education Sector in The Democratic Republic of Congo: An Efficiency, Effectiveness, And Equity Analysis.

World Bank (2018) Democratic Republic of Congo, country overview. Retrieved from https://www.worldbank.org/en/country/drc/overview. Accessed on September 14, 2018.

Yamauchi, F (2007) Social learning, neighborhood effects, and investment in human capital: Evidence from GreenRevolution India. Journal of Development Economics, 83 (1), Pp. 37-62.

Zeng, Z and Xie, Y. (2014). The Effects of Grandparents on Children's Schooling: Evidence from Rural China. Demography; 51(2): 599-617. doi:10.1007/s13524-013-0275-4. 